\title{
ПИТАННЯ БЕЗСПОЛУЧНИКОВОГО СКЛАДНОГО РЕЧЕННЯ В УКРАЇНСЬКОМУ ТА РОСІЙСЬКОМУ МОВОЗНАВСТВІ
}

\author{
Святобаченко I. С. Питання безсполучникового складного речення в українському та російському \\ мовознавстві. \\ Статтю присвячено аналізові розробки питання безсполучникового складного речення в \\ українському та російському мовознавстві, зроблено спробу порівняти аспекти та закономірності \\ дослідження зазначеної теми. Визначено тенденції подальшого розвитку вчення про безсполучникове \\ складне речення. \\ Ключові слова: безсполучникове складне речення, безсполучниковий зв’язок, складнопідрядне \\ речення, складносурядне речення.
} языкознании.

Святобаченко И.С. Вопрос бессоюзного сложного предложения в украинском и русском

Статья посвящена анализу разработки вопроса бессоюзного сложного предложения в украинском и русском языкознании, сделана попытка сравнить аспекты и закономерности исследования обозначенной темы. Определены тенденции дальнейшего развития учения о бессоюзном сложном предложении.

Ключевые слова: бессоюзное сложное предложение, бессоюзная связь, сложноподчинённое предложение, сложносочинённое предложение. linguistics.

Svyatobachenko I. S. The question of the asyndetic complex sentence in the Ukrainian and Russian

The article is devoted to the analysis of working-out the question of the asyndetic complex sentence in the Ukrainian and Russian linguistics, it is done a try to compare the aspects and the patterns of the research of the given topic. It is determined the tendencies of the further development of studying the asyndetic complex sentence.

Key words: asyndetic complex sentence, asyndetic connection, complex sentence, compound sentence.

Питання безсполучникового складного речення, зокрема його місця в системі мови, уже протягом тривалого часу залишається відкритим, попри чисельні дослідження з цієї проблеми українських та російських лінгвістів. Так, до кінця не вирішеним залишається питання типологізації зв'язку частин безсполучникового речення, провідних засобів вираження цього зв'язку, навіть сам термін «безсполучникове складне речення» варіюється залежно від аспекту, що є провідним для того чи того дослідника. 
Безсполучникове речення цікаве не лише своїми формальними особливостями (відсутність матеріально вираженого засобу зв'язку між частинами), а й своїм статусом у системі синтаксичних одиниць, що, 3 одного боку, протиставляє цей тип речень сполучниковим, що мають матеріально виражений показник зв'язку між частинами, 3 іншого, безсполучникове складне речення характеризується своєрідним граматикосинтаксичним оформленням, що різнить його зі зв'язком сурядності й підрядності. Так, цікавим постає факт існування двох і більше предикативних одиниць у межах однієї складної синтаксичної конструкції, семантична єдність яких може бути зумовлена як контекстом повідомлення (лінгвістичний чинник), так i паралінгвістичними чинниками, як-от емоційний стан мовця, темп мовлення i т. ін. Усе це мотивує актуальність дослідження, що спрямоване на встановлення особливостей поглядів різних лінгвістів на статус безсполучникового складного речення та його внутрішню організацію. У різні часи проблему безсполучникового складного речення досліджували такі вчені, як В. А. Бєлошапкова, А. А. Бронська, В. В. Виноградов, І. Р. Вихованець, Н.В. Гуйванюк, С. І. Дорошенко, А. П. Загнітко, М. С. Поспєлов, О. М. Пєшковський, I. І. Слинько, О. О. Шахматов та ін.

Мета нашого дослідження - простежити розвиток концепції безсполучникового складного речення в українській та російській лінгвістиці, виявити спільні та відмінні риси і визначити провідні аспекти дослідження зазначеної проблеми.

Практичне значення роботи полягає в тому, що матеріали дослідження можуть бути використані під час викладання загального курсу української мови, синтаксису, граматики, актуальних питань лінгвістики та в порівняльних дослідженнях української та російської мов.

Безсполучникове складне речення посідає особливе місце в синтаксичній системі як української, так і російської мов. 3 одного боку, воно, так само, як й інші види складних речень, характеризується комунікативною єдністю й завершеністю, а також наявністю складної пропозиції, що відбивається граматично в наявності двох або більше предикативних одиниць у межах одного безсполучникового речення. 3 іншого, - специфічні риси безсполучникового складного речення перебувають на периферії граматичного та комунікативного рівнів мови, оскільки відсутність формального зв'язника-сполучника значно впливає не лише на синтаксичну організацію речення, а й на комунікативну структуру усього висловлення: робить його експресивнішим, динамічнішим, до того ж повністю відповідає законові економії мовних засобів у висловленні.

На нашу думку, саме такою неоднозначною позицією й пояснюється те, що навіть сам термін «безсполучникове речення» і досі не $\epsilon$ загальновизнаним. Так, в українській лінгвістиці наявний термін «складні безсполучникові комунікати» (I. І. Слинько, Н. В. Гуйванюк, М. Ф. Кобилянська), що свідчить 
на користь того, що провідним у цій класифікації постає саме комунікативний аспект дослідження. Це явище не є безпідставним, оскільки безсполучникове складне речення, хоч і характеризується такою формальною особливістю, як відсутність сполучника, передбачає кілька пропозицій, які об’єднані одним комунікативним завданням, а також єдиною пресупозицією, що $\epsilon$ необхідною задля досягнення комунікативної мети, ефективного спілкування.

В. А. Бєлошапкова пояснює відсутність протягом тривалого часу вчення про безсполучникове складне речення в лінгвістиці тим, що досить довго увага приділялась фактам кодифікованої літературної мови, тоді як безсполучникові складні речення притаманніші розмовному мовленню.

Одним iз перших у російському мовознавстві питання безсполучникових складних речень торкнувся, хоч i побіжно, М. В. Ломоносов. Так, у своїй «Риториці» він звернув увагу на кількісну перевагу в художніх текстах саме складних речень, частини яких не поєднуються сполучниками.

О. О. Потебня пов'язував питання структури складного речення 3 видо-часовими формами дієслів, які в ньому функціонують, i, хоч i не досліджував безсполучниковий зв'язок як такий, проте зазначав, що послідовність дій у складному реченні не стільки виражається за допомогою сполучників, скільки саме через граматичні форми дієслів.

О. М. Пєшковський надавав безсполучниковому складному реченню особливого статусу: «...безсполучниковість, навіть якщо і вирізняти в ній відтінки підрядності і сурядності, варто у будь-якому разі відокремити від справжньої сурядності і підрядності» [6, с. 447].

О.О. Шахматов також зауважує особливості безсполучникових складних речень, проте розподіляє їх за двома типами: поєднувані сполуки (без сполучників, але з поєднувальними паузами) та супідрядні сполуки (iз відповідником підрядного сполучника - підрядною паузою). У цій концепції також вбачаємо вплив складних речень сполучникового типу (складнопідрядні та складнопідрядні) на теорію безсполучникового складного речення. Таким чином безсполучникове складне речення, 3 одного боку, вже виокремлюється як один із різновидів складних речень, що протиставляється сполучниковим складним реченням, 3 іншого, - не набуває абсолютної самостійності, оскільки його аналіз проводиться за аналогією до складнопідрядних та складносурядних речень, однак не йдеться про тип безсполучникових речень, що не можна однозначно віднести до того чи того виду, який згодом отримає назву «безсполучникове речення 3 недиференційованим типом зв’язку».

Заслуговує на увагу ще один погляд на безсполучникові складні речення: автори «Русской грамматики» (за редакцією Н. Ю. Шведової) не вбачають у безсполучникових складних реченнях опозицію сполучниковим, а самі речення вони називають «безсполучникове 
поєднання речень». Таке твердження небезпідставне, оскільки граматикосемантичні відношення між частинами безсполучникового складного речення найкраще вияскравлюються саме за розгляду всього контексту. Проте за розгляду всього повідомлення загалом як поєднання речень, одну текстову канву, що характеризується зв'язністю та смисловою єдністю, чи не виходить, що й увесь текст - єдине безсполучникове поєднання речень?

Першим у російській лінгвістиці неможливість розподілу безсполучникових складних речень за ознаками сурядності / підрядності зазначив В.В. Виноградов. Лінгвіст запропонував у поділі безсполучникових речень керуватися не інтонацією, а брати до уваги смислові та граматичні відношення в межах речення. Такий погляд найдоцільніший, оскільки безсполучникові складні речення являють собою саме смислову та граматичну єдність, а інтонація слугує засобом зв'язку окремих комунікатів, що формують єдиний масив інформації.

Визнає існування безсполучникових речень як окремого класу складних речень Н. С. Валгіна, коли говорить про те, що в російській мові наявні два типи поєднання частин складного речення - за допомогою сполучника і без нього, а відтак - i два види речень - сполучникові та безсполучникові. Безсполучникове речення авторка визначає як «складне речення, частини якого пов'язані за смислом, інтонаційно, співвідношенням видо-часових форм дієслів-присудків та порядком розташування частин. Основна ознака безсполучникового речення - відсутність сполучників і сполучних слів» [1]. Проте поділ безсполучникових речень на сурядні та підрядні лінгвістом не визнається: «Оскільки смислові відтінки й інтонаційні ознаки можуть поставати недостатньо диференційованими, класифікація безсполучникових складних речень не має чітко вираженого й окресленого підгрунтя» [1]. Натомість значна увага у класифікації безсполучникових складних речень надається структурним особливостям. На думку Н. С. Валгіної, існує два різновиди безсполучникових складних речень: речення зі структурно-зумовленими частинами, які характеризуються наявністю в одній із частин займенника, вказівного слова, прикметника, дієслова і т. ін., що потребують подальшого роз'яснення / уточнення: Мол, всё понятно - вон какой Третьяк оказался прагматичный (3 журналу), або ж які, навпаки, замінюють слова, що трапляються в попередній частині, або й усю частину загалом: Раньше моё серие разрывалось на части - так я скучал по дому (3 журналу).

В українській лінгвістиці також представлені різні погляди на визнання безсполучникових складних речень як окремого різновиду складного речення в синтаксичній структурі мови. Так, у «Курсі сучасної української літературної мови» (за редакцією Л. А. Булаховського) зазначено: існують лише два різновиди безсполучникових речень - безсполучникові складносурядні та безсполучникові складнопідрядні речення. 
Поширеною в українській лінгвістиці є думка про три різновиди безсполучникових складних речень: безсполучникове складносурядне речення, безсполучникове складнопідрядне речення та безсполучникове складне речення 3 недиференційованим синтаксичним зв'язком між частинами (I. Р. Вихованець, С. Чорній). Ця теорія точніше відбиває специфіку безсполучникових складних речень у системі мови, аніж попередня, проте не надає їм статусу одиниць, що характеризуються власними засобами сполучуваності, мають власну парадигму та закономірності функціонування.

Іще один погляд, який видається досить коректним, розвиває Л. О. Кадомцева: «Безсполучникові складні речення - це тип складних речень, у яких значеннєва залежність між складовими частинами виражається сукупністю формальних засобів без застосування сполучників - порядком складових частин речення, інтонацією в иii синтаксичній функції, видо-часовою узгодженістю форм присудків» [11, с. 409]. Авторка не заперечує схожості смислового зв’язку безсполучникових складних речень зі сполучниковим зв'язком у складносурядних чи складнопідрядних реченнях, залежно від контексту, однак не надає цьому критерієві вирішального значення у класифікації безсполучникових речень за характером зв'язку. Лінгвіст звертає увагу на те, що в частині безсполучникових складних речень підстановка сполучника можлива, за умови, якщо частини безсполучникового складного речення знаходяться в одній значеннєвій площині, і називає такі речення асиндетонними. На нашу думку, термін «асиндетонні» характеризує не формально-граматичний, а стилістичний аспект функціонування речення і у своєму визначенні спирається на контекст усього повідомлення та структурні особливості складників комунікативного акту загалом, може співвідноситися з поняттям «період». За визначення речення як безсполучникового до уваги беремо саме формально-граматичний та смисловий бік синтаксичної одиниці.

В україністиці прибічником теорії самостійності безсполучникових складних речень є С. І. Дорошенко: «Безсполучникові складні речення структурно-семантичний тип складних конструкцій. У безсполучниковому реченні організація всієї структури спирається не на сполучникові і сполучні слова, а на граматизовані елементи, що виконують важливу конструктивну роль у граматичному оформленні складного речення. Такими елементами $\epsilon$ порядок розташування предикативних частин, видо-часова, часово-способова і способово-модальна співвідносність дієслів-присудків, наявність лексем відповідної семантики, порядок слів у предикативних складниках, відповідне інтонаційне оформлення частин і всієї синтаксичної конструкції» [2, с. 545]. Лінгвіст звертає увагу на те, що хоч предикативні одиниці в межах безсполучникового речення i $\epsilon$ відносно незалежними одна від одної, порівняно зі складнопідрядними та складносурядними реченнями, частини 
яких поєднуються за допомогою сполучників, проте вони формують єдину комунікативну одиницю $\mathrm{i}$ не завжди $\epsilon$ семантично незалежними та рівноправними, оскільки в більшості безсполучникових речень «одна частина щодо іншої виступає або роз'ясненням, або уточненням, або коментарем, або виражає додаткове зауваження, мету, час чи умову, тобто семантично супроводжує іншу. Саме в такому співвідношенні, коли одна 3 частин, будучи формально незалежною, значеннєво функціонує для іншої, граматичні зв'язки нейтралізуються: семантична підпорядкованість нейтралізує формальну незалежність» [3, с. $21-22]$. Мовознавець обстоює думку про неможливість прирівнювання безсполучникового речення до складносурядного / складнопідрядного, оскільки безсполучниковість зумовлює багатовимірність семантики складного речення, за якої вставлення певного сполучника не відбиває адекватно думки мовця / письменника.

Визнання безсполучникових речень як окремого типу складних речень знаходимо і в роботах сучасних мовознавців М. У. Каранської, А.П. Загнітка та ін. Так, А.П. Загнітко слушно зазначає: «Безсполучникове складне речення відрізняється від рівновеликих сполучникових складнопідрядних і складносурядних речень тим, що в об’єднанні його частин використовуються як спільні для безсполучникового i сполучникового типів зв'язку засоби, так і суто специфічні» [4, с.733].

Серед специфічних засобів зв'язку частин безсполучникового речення - наявність спільного граматичного члена: Зелений лист тоді обтяжений прозорими краплями, китяги недоспілих яблук оздоблені рубінами, топазами, аметистами (У. Самчук); синсематичні слова в одній із частин: Стільки разів сходило для неї соние, стільки разів переживала насолоду буття, стільки разів бачила або відчувала небо, запах сонячного тепла ц̌ землі (У. Самчук); наявність конструктивної неповноти одного зі слів частин, що потребують доповнення, роз'яснення: Сквозь сон чудилось - то вроде заболел, то отходил маленько (О. Солженіцин); взаємодія модально-часових форм дієслів-присудків: Покупатель получает сертификат подлинности, ему также предлагают роскошно организованную поездку и личную охрану... (3 журналу).

М. У. Каранська так потрактовує безсполучникове складне речення: «Складне речення називається безсполучниковим, якщо синтаксичний зв'язок між його компонентами встановлюється без участі сполучника» [5, с. 258]. Як бачимо, провідним чинником у цій класифікації виступає саме формальний, на основі нього авторка i виокремлює безсполучникові складні речення. Однак далі зазначається: «Семантикосинтаксичні відношення між компонентами безсполучникових речень $\epsilon$ близькими то до сурядних, то до підрядних, проте в них переважають свої окремі особливості, тому їх виділено в окремий клас складних речень поряд iз складносурядними i складнопідрядними» $[5$, с. 258]. Це ๑ І. С. Святобаченко, 2011. 
твердження, на нашу думку, є не зовсім правомірним, оскільки, по-перше, безсполучникове речення наближається до складносурядного / складнопідрядного скоріше у свідомості мовця, аніж за своєю природою як такою: саме мовець намагається у процесі декодування інформації встановити тип зв'язку за допомогою сполучника для адекватного відтворення послідовності / причиновості / наслідковості тих чи тих фактів дійсності. По-друге, варто говорити про те, що безсполучникове речення визначається у площині сполучниковості / безсполучниковості, а не безсполучниковості / сурядності / підрядності, оскільки провідним чинником виокремлення $\epsilon$ все-таки його найяскравіша формальна характеристика - відсутність сполучника між його компонентами.

Про розбіжність між сполучниковими та безсполучниковими конструкціями згадує й I. І. Слинько: «Вони часто близькі, але «повного збігання тут нема», бо: 1) значення безсполучникових поєднань менш диференційовані; 2) можливості вираження деяких значень засобами безсполучниковості обмежені, наприклад значення розділові, порівняльні, цільові і допустові» [9, с. 634].

Можна говорити про те, що теорія безсполучникового складного речення в українській та російській лінгвістиці розвивалася рівнобіжно. Загалом, виокремлюється три основні підходи до розгляду безсполучникового складного речення та безсполучникового зв'язку: безсполучниковий зв'язок на основі формального чинника протиставляється сполучниковому, проте в межах безсполучникового складного речення розглядають безсполучникове складносурядне речення та безсполучникове складнопідрядне речення, до яких додається безсполучникове речення 3 недиференційованим синтаксичним зв'язком між частинами; другий погляд потрактовує безсполучникове складне речення як таке, що корелює зі складносурядним та складнопідрядним складним реченням, його вживання зумовлене комунікативними настановами та ситуацією мовлення, а також позамовними чинниками. Прибічники такого підходу заперечують можливість виокремлення безсполучникових складносурядних та безсполучникових складнопідрядних речень, мотивуючи це тим, що неможливо адекватно відбити усі відтінки значення безсполучникового складного речення за підстановки певного сполучника. Третій підхід розглядає безсполучникове складне речення як контекстуально залежну одиницю мовлення, водночас надаючи їй текстотвірної функції.

Термін «складне речення» корелює в наведених концепціях із термінами «поєднання речень», «комунікати». На нашу думку, термін «поєднання речень» відбиває явище формальної єдності речень, проте не зазначає семантичної цілісності. У складі ж безсполучникового складного речення кожна з частин контамінується, унаслідок чого виявляються нові 
відтінки значень, що узгоджуються із комунікативною настановою безсполучникового речення загалом, а не кожної з частин окремо.

Термін «комунікат» вдало відбиває здатність безсполучникового складного речення вживатись здебільшого в розмовному мовленні, проте не бере до уваги існування схеми утворення безсполучникового складного речення в мові як такого. Безсполучникове речення за такого підходу розглядається узусно, спираючись на ситуаційність мовленнєвого акту. Провідним чинником у цьому разі $є$ контекст повідомлення. Автори ж «Русской грамматики» підійшли до цього питання глобальніше мовознавці розглядають речення не як окрему мовну одиницю, що входить до складу тексту, самому реченню вони надають текстових ознак, а відтак і безсполучниковому зв'язку надається текстотвірна функція. Таке розуміння притаманне і сучаснішому напряму мовознавства - дискурсології.

Попри те, що питання безсполучникового речення розглядається протягом досить тривалого часу (зокрема, статусу окремого виду складного речення безсполучникове речення набуло у 50-х роках XX століття), досліджувані у статті проблеми й досі залишаються до кінця не вирішеними або ж на них немає однозначної відповіді.

Окрім питання статусу безсполучникового речення, зацікавлення викликає i його актуальне членування, що характеризується багатоступеневістю, а також синтагматичне членування, що посідає проміжне місце між поверхневим синтаксисом речення та його комунікативною структурою. Досліджувані проблеми потребують вирішення задля чіткішого пояснення процесу породження безсполучникового складного речення та принципів розподілу інформації між його частинами.

\section{Література}

1. Валгина Н. С. Синтаксис современного русского языка [Електронний ресурс]. Режим доступу: http://www.hi-edu.ru/e-books/xbook089/01/

2. Дорошенко С. І. Безсполучникові складні речення // Український синтаксис : навчальнопрактичний комплекс : у 2-х ч. / А. П. Загнітко, М. О. Вінтонів, Л. В. Сегін. - Донецьк - Слов'янськ : ДонНУ, 2010. - С. $545-552$.

3. Дорошенко С. I. Складні безсполучникові конструкції в сучасній українській мові / С. І. Дорошенко. - Харків : Вища школа, 1980. - 151 с.

4. Загнітко А. П. Теоретична граматика сучасної української мови. Морфологія. Синтаксис / А. П. Загнітко. - Донецьк : ТОВ «ВКФ «БАО», 2011. - С. 731 - 741.

5. Каранська М. У. Синтаксис сучасної української літературної мови : [навч. посібник] / М. У. Каранська. - К. : Либідь, 1995. - 312 с.

6. Пешковский А. М. Синтаксис в научном освещении / А. М. Пешковский. - [2-е изд.]. - М., 1920. -504 с.

7. Поспелов Н. С. О грамматической природе и принципах классификации бессоюзных сложных предложений // Вопросы синтаксиса современного русского языка / Под ред. В. В. Виноградова. - М., 1950. - C. $338-355$.

8. Русская грамматика : в 2-х т. / [глав. ред. Н. Ю. Шведова] . - Т. 2. - М. : Наука, 1980. - С. 634-657.

9. Слинько I. І. Синтаксис сучасної української мови : Проблемні питання : [навч. посібник] / I. І. Слинько, Н. В. Гуйванюк, М. Ф. Кобилянська. - К. : Вища школа, 1994. - 672 с.

10. Современный русский язык : [учеб. для филол. спец. ун-тов] / В. А. Белошапкова, Е. А. Брызгунова, Е. А. Земская и др.; Под ред. В. А. Белошапковой. - [2-е изд., испр. и доп.]. - М. : Высшая школа, 1989. - С. $763-772$.

11. Сучасна українська літературна мова. Синтаксис / за заг. ред. І. К. Білодіда. - К. : Наукова думка, 1972. $-515 \mathrm{c}$.

Стаття надійшла до редакції 16.11.2011 p.

(C) І. С. Святобаченко, 2011. 